\title{
Masculinities, Attachment Theory and Transformative Learning: A Discussion of Some Theoretical Considerations for Developing an Emotionally Secure Teaching Praxis
}

\author{
by DAMIEN CARBERRY \\ City of Dublin Education and Training Board
}

\begin{abstract}
This paper situates education as an integral component of the overall prison rehabilitation process. The article discusses how an educational practitioner's knowledge of attachment theory and masculinities can be utilized to develop a secure methodological teaching environment in the classroom of a prison education unit and create a space where transformative learning can take place. The link between attachment theory and the social and institutional composition of masculinities are considered for their influence on perceptions and concepts of the masculine self and masculine identity in general. The practitioner who is cognizant of these issues has the potential to develop secure methodological frameworks that focus on creating a nurturing learning environment that has the potential to provide students with a space to safely reflect, examine and potentially transform their learning experiences and thus their sense of self.
\end{abstract}

Keywords: prison education; attachment theory; transformative learning; masculinities

It's a characteristic of human nature that the best qualities, called up quickly in a crisis, are very often the hardest to find in prosperous calm. The contours of all our virtues are shaped by adversity.

(Roberts, 2003, p. 379)

Education has been shown to have a positive effect on inmate behaviour while in prison; it also contributes to a successful re-entry into society and reduced rates of recidivism post-release. Studies have consistently revealed the constructive contribution education has made to the lives of incarcerated men. (Gerber and Fritsch, 1995; Fabelo, 2002, Lochner, \& Moretti, 2004; Esperian, 2010; Hughes, 2012; Mastrorilli, 2016; Utheim 2017). Education offers a way for men to occupy their time in a positive and productive manner. In adding to this accepted premise, this paper presents a theoretical hypothesis for the development of a teaching praxis that places the emotional learning development of the student at the centre of a fulcrum for transforming the view of self. By introducing these concepts, it is hoped that practitioners will consider ways to develop and incorporate the ideas into their practice. Furthermore, it is anticipated that this will generate further theoretical exploration and practical interdisciplinary research across education in prison services.

Daniel Goleman (2004) argues that emotional intelligence forms the fundamental basis for our learning experiences. In line with Goleman's premise, this paper considers attachment patterns in defining the emotional life histories of these men. Attachment theory has been utilized to frame various prison based research. A study of young males in a German prison examined the correlation between attachment style, interpersonal problems and violent behaviour. Ross and Friedemann (2007) revealed that relationship instability, poor emotional attachment and insecure attachment styles were dominant characteristics among this group. In a US based study, the authors discovered that so called "lifestyle" criminals displayed a strong avoidant attachment pattern (White and Walters, 1991). From a Scandinavian context Hansen, et al (2011) suggests that there is a correlation between types of anti-social behaviour and types of attachment patterns. Based on his finding from studies on young male offenders in UK institutions, Harvey (2007) concludes that those who entered the institution with a secure attachment base were much more capable of adapting to life on the inside, while those

Correspondence: Damien Carberry, Email: damiencarberry@gmail.com

(Accepted: 12/27/2017) ISSN: 2387-2306 doi: http://dx.doi.org/10.15845/jper.v4i2.883

Except where otherwise noted, content on this site is licensed under a Creative Commons Attribution 4.0 International License.

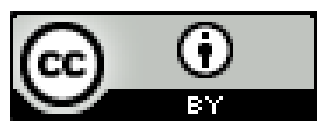


with insecure bases struggled to do so. He suggests that staff within the prisons system can fulfil a care-giving role and provide the necessary support to facilitate the transition. These studies are valuable for what they reveal, but they come from a criminal justice and/or medical perspective.

This paper considers the use of attachment through an educational lens where education is viewed as an integral and composite component of the rehabilitation process. The underlying premise presented here is that education is not just about certification - although this is an important element - but that educational learning is a developmental process involving cognitive, emotional and socio-linguistic dimensions. Through utilising attachment theory, the educator can adopt the role of an emotionally aware educational attachment figure. Acting in this capacity in the classroom, the educator is uniquely positioned to cultivate the emotional learning space and provide an environment where secure attachment patterns can be nurtured and incorporated into the teaching methodology. If the learner is not emotionally secure, cognitive and socio-linguistic learning will be hampered. Consequently, having an understanding and awareness of factors that influence masculine identity, development and behaviour will provide the educator with a framework from which to develop a strategic approach in constructing their teaching methodology. Masculinities are learned behaviours that are being constantly structured and reconstructed on a daily basis (Connell, 2000, 2001, 2002).

Therefore, working as a teacher in a male prison raises issues that are educationally specific to this setting. Practitioners come face to face with men who have transgressed society's rules and are consigned to live out segments of their lives confined behind the walls of a penal institution. A prison education unit is a space fraught with adversity. Within this walled setting, educators and students bring their cumulative life-experience, cognitive understanding and emotional intelligence. Attachment experiences have shaped all our lives. This in turn has affected internalisations of our gender identity, conditioned in the social setting of our communities and by the structural institutions of the state. These experiences serve to shape a persons' thinking and feeling processes. By developing an awareness of these influences, an individual's sense of self can be examined and reframed and perspectives transformed.

This paper argues that there is as interconnectedness between attachment, masculinity and transformative learning, which can be developed as an emotionally aware teaching methodology and utilised in the classroom of the education unit, leading to the development of attachment informed transformative learning experiences for students. Education in prison is considered through the perspective of attachment theory in order to present a hypothesis for how attachment related emotions has the potential to inform the practice of transformative learning methodology and add a component to the practitioners' professional approach to the practice of teaching in this environment. The article outlines the origin and development of attachment theory, considers the processes of transformative learning, and sets these within a framework for understanding the complexities of masculinities in a sociological context. The benefits of engaging with the practical implementation of this knowledge and developing it into an emotionally grounded praxis are then discussed.

\section{Defining Masculinities}

\section{Socio-Cultural Masculinities}

Definitions of manhood, manliness, maleness and masculinities are contested. These cultural and social characterisations are not without ambiguity nor do they go unchallenged. They are fluid and interchangeable, and conditional through association with distinctive cultural and social interpretations that underpin their meaning. These configurations are socially and culturally defined and have served to shape and are shaped by historical events (Brod and Kaufman, 1994; Connell, 2001, Kimmel, 2005, Reese, 2010). Masculinities are socially and culturally based and are reflected in the structures of governments and state institutions. Taking Gamsci's concept of hegemony as the basis for the construction of an analytical framework, Connell (2001) suggests that masculinities can be understood as negotiated relational male identities, defined within the social and cultural milieu of the power dynamics of hegemonic, complicit, subordinate and marginalized. Hegemonic masculinities are the dominant configurations of male identities that exist within a social setting and are reflective of the ideas and beliefs of those in positions of power or authority in that context. The complicit position benefits from the hegemonic order without challenging the obvious anomalies of injustice and dominance that pertain to it. In this categorisation the marginalisation of others is ignored or overlooked for the benefit of self. Thirdly, subordinate masculinities don't match up to the 'legitimacy' of the hegemonic order 
and are subject to social dominance by the former. Words such as wimp, sissy, mama's boy and puff are further reflections of men categorised in this status. An abusive ritual of condescension that aligns the subordinate position with femininity is a prominent. Those in the marginalised position find themselves at the extreme of the hegemonic norm - at the margins of society due to social class or race. These four categories can be taken and utilised to analyse the power relations that exist within groups or subgroups within any social context. The analytical groupings are relational and subject to the practice that pertains to social interaction that involves men's power relations. "These two types of relationship - hegemony, domination/subordination and complicity on the one hand, marginalization/authorization on the other - provide a framework in which we can analyse specific masculinities" (Connell, 2001, p. 81). These analytical categories of hegemonic masculinities and marginalised masculinities are not fixed male types, but compositions of interactions conditioned on systems of relations within social settings. They are both outwardly visible and internally conceptual. As discussed later, this has significant implications when considering the development of attachment patterns in the life-course of men and the application of transformative learning theory for education in prisons, particularly in terms of the perceived subjugation of the incarcerated body.

Hegemonic models and practices of masculinities carry all the public status of power and legitimacy provided that the individual subscribes to its pervasiveness. In terms of gender identity, there is a perception that men must be dominant in and masters of the public sphere (Hearn, 1992). This is a space where masculinities are played out in the public spaces of our streets, institutions, workplaces, media and visible spaces in our societies. There is a crucial element of masculine identity that is concomitant, mutually inclusive, yet mostly contrary to the hegemonic project - the private domain. The private domain of masculinities represents men's relationship with and within the self. This is where the issue of self-awareness takes on an increasingly important function in the quest for male autonomy (Connell, 2002; Aboim, 2010). "If the public world of men is rooted in myth and mystery, then men's private lives can appear deep, dark, almost gothic in their impenetrableness" (Whitehead, 2007, p. 146). Moreover, these public stereotypes of rationalised emotional belief can be deemed to shape perceptions and understanding of emotional behaviour in other people and influence an individual's current and future emotional awareness and health (Timmers, Fischer and Manstead, 2003, Pease, 2012). Moreover, "at the heart of the private domain [is] trust intimacy and emotion" (Whitehead, 2007, p. 168). It is in this private domain that attachment patterns have the potential to be (re)negotiated and determined. As discussed later, addressing this aspect of masculine identity through considered teaching methodologies offers transformative educational opportunities for both teachers and students.

\section{State Masculinities}

Gender identity is contextual, based on the social and cultural politics that define any given society in space and time. Viewed through this lens, the education and justice systems have served to shape the lives of incarcerated men and has defined their sense of reality in specific ways. There is a relational framework between the masculine nature of state institutions and the pervasive masculinities associated with them. These institutions represent a complex set of social and cultural values that manifest as symbolic criteria, which transmit aspirational connotations for social and cultural reproduction under which state hegemonic masculinities are negotiated. The state is a hegemonic masculine entity and this is reflected in its institutions, historically constructed on the basis of ideologies, warfare and political principles that were shaped and contextualised by men (Bloom et al, 2000, Dudink, et al, 2004). Similarly, the state apparatuses that uphold civil order and deliver social administration are reflective of these same historical underpinnings. Internal change has taken place, but the overall structure of the state as an institutional model reflects a masculine hegemonic order in the nature of the values that underpin its origins - it was conceived and crafted by men (MacKinnon, 1989; Connell, 2003; Yuval-Davis, 2006). State institutions, such as the education and justice systems, form part of this same hegemonic state framework for how the curricula for the former and punishment and rehabilitation policies of the latter are reflective of what Gramsci termed the dominant order. The education system, its administration and daily application reflect the cultural value of those in positions of authority and power. They delineate the terms and content of curriculum and policy and inadvertently contribute to social exclusion. Mayo outlines Gramsci's position as follows:

The agencies, which, in his view, engage in this educational relationship, are the ideological 
social institutions, constituting civil society, such as law, education, mass media, religion etc. Gramsci argues that, in Western society, the State is surrounded and propped up by a network of these institutions that are conceived of as 'a powerful system of fortresses and earthworks' which makes its presence felt whenever the State 'trembles' (Gramsci, 1971, p. 238; Gramsci, 1975, p. 866). As such, social institutions such as schools and other educational establishments are not 'neutral' but serve to cement the existing hegemony, therefore being intimately tied to the interests of the most powerful social groups. (Mayo, 2008 p. 420)

These hegemonic institutions reflect the attitudes and outlook of those in positions to influence its makeup. Their perspective and attitude determine the framework and ethos of the relevant institutions and their internal and external cultural influences. They reflect state masculinity in terms of the unpinning cultural and social values and thus create a gendered society (Kimmel, 2016).

Therefore, the education system serves to foster cultural reproduction by promoting class-based values and celebrating the symbolic importance of credentials and status whilst consequently reproducing social inequalities (Giddens, 2009, pp 826 - 881). For example, 'hidden curriculum' of formal schooling reflect the economic moral, ethics and ethos of discipline, hierarchy and subservience to the needs of global capitalism-a model built on male theoretical constructs of order, production and economic values (Hewitson, 2001, Harvey, 2005, Hill and Cole, 2004). Educational systems also exert a powerful influence on shaping gender identities (Eden, 2017).

Schools have a gendered division of labour, and a curriculum marked by a history of gender division and patriarchal control of knowledge, Schools are setting for the drawing (and erasing) of gender lines in everyday interaction, for the creation of a hierarchy of masculinities, as well as for the contestation of gender subordination... And what is true for...education is true for other sectors of the state. Seeing gender as a social structure, one of the ways collective social processes are shaped, makes it possible to analyze the state as a gendered institution and inherently a site of gender politics. (Connell, 2003, p. 16)

According to Share et al (2007), the structure of the Irish education system reflects the values of the socially advantaged - a position that maintains this social dominance. Poor attachment to education tends to be a definitive aspect in the experiences of men in prison communities. "The majority of Irish prisoners have never sat a State exam and over half left school before the age of 15" (Irish Penal Reform Trust, http://www. iprt.ie/prison-facts-2, 2017). The conventional education system can be seen to have a marginalising effect on this section of the population. Education plays a major role in shaping and directing gender identities (Biddle, 2001; Skelton et al, 2006). The formal education system is also influential in shaping the social and cultural relations that influence the reproduction of masculinities, relative to class and social status (Connell, 2000, p. 106). Negative socio-economic factors and poor role models influence criminality and consequently the prison populations have a disproportionate number of inmates with these life histories (Vacca, 2004, p. 301). It is not surprising to discover that the dominant imposing model of locally defined hegemonic masculinity practices, constructed on fear, intimidation and violence, have an exalted status in marginalised communities. For men from less privileged background these practices of domination offer access to power and status within the local communities (Evans and Wallace, 2008, p. 485). Although the make-up of the hegemonic order is different, the model of dominance remains transposable in social settings. Negative education attainment is a feature of the lived experiences of large majority of prison inmates (Farrington, 2002). Low literacy and numeracy abilities are common among male inmates in Irish prisons and the vast majority have not completed their Junior Certificate. Many of these men have experienced marginalisation from the mainstream education system (Behan, 2010). This has significant implications when considering the development of attachment patterns in the life-course of men and the application of transformative learning theory for education in prisons, particularly in terms of the perceived subjugation of the incarcerated body. I acknowledge there are many other complex issues that contribute to advantages and disadvantages in society that are beyond the scope of this paper. However, the norms and values that underpin the education system appear not to gain traction in the marginalised communities from which these men originate. This has implication for masculine identities 
that are formed under these conditions.

\section{Masculinities in Prison}

Criminality is acknowledged as an activity predominated by men. "Three major findings from criminological literature on the relationship between gender and crime are that men commit more crimes, men are more violent, and men are more likely to find themselves involved with the criminal justice system" (Cohen and Harvey, 2006, p. 231). A snapshot of the average number of prisoners under sentence in Irish prisons on 30 November 2016 revealed that out of a total 3,077, 95 were female (Irish Prison Service Annual Report, 2016, p. 28). For 30 November 2015 the total number was 3, 150 of which 115 were female (Irish Prison Service Annual Report, 2015, p. 24). Although the total average dropped slightly, and the gender gap broadened, the figures reveal an overwhelmingly disproportionately higher number of men in the Irish prison system compared to women. The figures for previous years reveal a similar pattern. (http://www.irishprisons.ie/index. php/information-centre/publications/annual-reports/)

As a component of the hegemonic state structure, the penal justice system exercises power and authority over the bodies of those deemed guilty of a range of socially, judicially and politically defined transgressions. Prison has a function in society; it is the nature of that system and the practices that pertain to it that is open for debate. This is why it is important to examine the social systems that present the conditions for the men who end up in incarcerated communities. People who are subjects of prejudice, institutional or personal, intentional or unintentional, experience social marginalisation. The prison population in Ireland is disproportionately comprised of men from marginalised sections of society. Many of their lives have been defined by social deprivation such has health issue, addiction, unemployment and parental imprisonment (Bacik et al, 1998; King, 2002).

Within prison communities the fact that so many men live in such close proximity to each other raises the issue of the male practices and behaviours that pertain within these domains. Social norms and values are relocated from communities and cast into the context of the confined spaces that (re)define prison environment. Within the Irish prison system the majority of those incarcerated are "25 times more likely to come from and return to a seriously deprived area" (IPRT, http://www.iprt.ie/prison-facts-2, 2017) pointing to a link between masculinities, crime and social marginalisation. Hegemonic masculinities are both institutional and indigenously based. Within working class areas the hegemonic, complicit, subordinated and marginalised are representative of the locally established hierarchy that pertain to these places, conditioned by collective definitions of that community within the wider social framework (Haywood and Mac'anGhaill, 2003). Given that the majority of incarcerated men are from disadvantaged backgrounds, their socially defined and constructed male identities are transferred into the prisons and redefined within the pressurised communities that exist within the institutions. These identities are further compounded by the hegemonic, hierarchical and authoritarian nature of the prison regime and often manifest themselves in intense and exaggerated representations of masculinities transferred from the outside communities (Jewkes, 2002. pp. 55-7). Just as many have felt rejected and ostracised by the hegemony of contemporary society and its institutions, this sense of marginalisation is further compounded by the structure of the prison regime and peer influences. Sabo et al (2001) outlines how the prison system mirrors the hegemonic power dynamic of society in general, but in a more extreme form. They argue that the prisons system accentuated hegemonic enactments of masculine gender politics within the walls of the institution.

Considering the cultural dynamic that operates within the walled and barred community that corrals groups of men into confined spaces, enacting masculinities is central to the social politics and personal identities that pertain under these conditions. Previous patterns and models of attachment are codified and intensified in this context. The institution of prison can be viewed as a community of masculine performance, from inmates to prison officers. Prison is a place where the use of threats and violence to dominate other males is an everyday norm. In fact it is suggested that masculinities acts as a psychological imprisonment within the physical structure of the penal institutions (Evans and Wallace, 2008). Karp (2010) has argued that male culture within prison communities emphasises hypermasculinity as a reification of maleness and defines men's interaction as associations rather than friendships. As masculinities are socially defined, paradoxically, prison exacerbates the very characteristics of manhood that lead to crime and little determined attention is given to 
interventions that help inmates re-define their masculinities in a positive manner. In this setting, asserting ones masculinity regularly takes on the form of physical aggression. The nature of masculinities in prison is an environmentally and circumstantially based reconstruction of manhood brought about thorough the power dynamics of social control and resource deficit (Phillips, 2001). These studies reveal that for masculinities within the prison system, serious challenges exist regarding issues of trust, intimacy and emotional development. Therefore, finding a space for engaging in personal reflection is even more important in this setting, if the overriding concern of male identity is focused on self-preservation and masculine performance. For educators, it is essential that we have a constant awareness of the environment that has shaped the lives of the students, as well as the environment they interact with on a daily basis.

The education unit within the prison offers an alternative site for (re) negotiating masculine identities a different educational paradigm from that of the hegemonic conventional model. The education unit can be a place of nurture within the mainstream masculine prison institution. The teacher working in this environment occupies a unique position of influence, one fraught with difficulties, yet tantalising in potential. However, because of the nature of these issues and the complexities of the prison environment, it is vital to consider the type of methodological approach that can be adopted to address these concerns. The education units offer a space of difference from that of the main prison community, and transitioning the space is difficult. When a student exits the door of the school at the end of the day, he is faced with the hyper-masculinities of the extended prison community. These issues are outside the control of the teachers; notwithstanding, educators need to consider them carefully when employing teaching methodologies in the school space. The following sections discuss how attachment and transformative learning offer scope for the development of an educational approach that is essential in this environment due to their insight and transitional possibilities.

\section{The Basis of a Teaching Methodology: Attachment Theory and Transformative Learning Theory}

\section{Attachment Theory}

Attachment theory has its origins in the work of John Bowlby and Mary Ainsworth (Bretherton, 1992). Bowlby's seminal work highlighted the ways in which peoples' emotional relationships develop in early childhood and have a definitive effect on how a person - through their life-course - engages with experiences that have similar emotional connotations. The individual creates internal working models of relationship types, constructed on the basis of trust, established with the primary caregiver in early childhood. The composite nature of this historical relationship defines how the child develops his/her relational connection to significant people in early life. The ways in which the child's personal security needs are met by the primary caregiver will define the child's expectations and concept of self in subsequent and future relationship situations. Bowlby claimed that these emotional patterns are part of the process of identity development, informing the child's emotional intelligence and influencing their relationship models throughout their life-course (Bowlby, 1969, p. $348 ; 1973$, p. $367 ; 1979$, p. $129 ; 1988$, p. 27 ; p. 126).

Bowlby found that maternal parenting was about delivering the appropriate responses to the infant's needs. If the parent is unaware of, or not responding or providing inappropriate responses, the evolving relationship creates an insecure attachment pattern in the child and forms the basis for their expectations for subsequent relationship. This leads the child to assimilate new relationships to existing models of attachment, leading "to various misconceived beliefs about the other people, to false expectations about the way they will behave and to inappropriate actions, intended to forestall their expected behaviour" (Bowlby, 1979, p. 142). On the other hand, if children have positive attachment experiences they are more likely to develop a greater sense of personal security, strategies for seeking out help and a more positive view of social relations (Fleming, 2007). This has crucial implications for the development of personal identity. Bowlby observed that a primary attachment figure who responds positively to the child's needs appeared to provide the infant with a prudent foundation for positive emotional development and the basis for constructing a secure sense of personal identity (Bowlby, 1988, p. 11).

Through empirical studies Ainsworth extended Bowlby's framework and identified different categories of attachment (Ainsworth, M. D., Blehar, M. C., Waters, E., \& Wall, S. 1978). Their laboratory studies, known as the 'The Baltimore Project', identified the 'strange situation' as a means of assessing these categorisations. 
The Strange Situation is a 20-minute miniature drama with eight episodes. Mother and infant are introduced to a laboratory playroom, where they are later joined by an unfamiliar woman. While the stranger plays with the baby, the mother leaves briefly and then returns. A second separation ensues during which the baby is completely alone. Finally, the stranger and then the mother return. (Bretherton, 1992, p. 17)

In monitoring the child's emotional responses to the various scenarios, Ainsworth found that some children were avoidant and angry with the mother on her return, while others sought security and comfort. When compared with data collected from the mother child interaction at home, the findings revealed that infants who displayed the former attributes had a more troublesome relationship with the mother at home than those who displayed the latter traits (Bretherton, 1992). From these observations the 'secure base' concept became a significant feature of attachment theory as it provided a means of assessing and categorising the emotional responses of an individual when faced with novel and psychologically challenging circumstances. "In discussing insecure attachment the authors described how physical, social and cognitive development all correlate with children's attachment classification" (Kennedy, 2008, p. 213).

Expanding on this framework, Main and Solomon (1986) identified the category of disorganised attachment (type D). This pattern is characterised by experiences that were frightening in their relationship with their primary caregiver. Children classified in this category are at the extreme end of the maladjustment spectrum and are more likely to display aggressive behaviour in childhood and through to adolescence and adulthood. Carlson (1998) found impairments in their emotional, social and cognitive development, with feelings of 'dissociation' where continuity of consciousness was disrupted and particularly accentuated under stressful conditions.

Attachment behaviour characterises humans from the cradle to the grave and becomes evident when adults are under stress, become ill, afraid or in emergencies. Patterns established in childhood endure into adulthood and tend to structure the way we interact and relate. Attachment style and behaviours persist through life and undergo developmental transformation. Adult attachments are linked to one's own childhood during which internal working models were constructed and in turn influence one's own parenting behaviour and ability to create secure attachments. The intergenerational dimension is important. (Fleming, 2007, p. 85)

For educators, the range of attachment patterns can elucidate the ways in which adult men make meaning and develop masculine identity, based on these historical, emotionally established internal working models of social interactions developed from early childhood (Bowlby, 1969, 1973). For example, when faced with the 'strange situation' of prison, the need for emotional security intensifies (http://www.who.int/mental health/ policy/mh in prison.pdf) and the modes and patterns of dealing with the contingent feelings are accentuated. This is because "the model of the attachment figure and the model of the self are likely to [have] develop[ed] so as to be complementary and mutually confirming" (Bowlby, 1973, p. 238). When considered in the context of masculine identity, these internal working models of self have a prevailing influence for how men view their identities as men. This also needs to be considered in the context of the education unit, as historical experiences of school may also hold negative emotional connotations for these men. The important point here is that attachment offers a spectrum for attempting to understand the emotional underpinning of male behaviour and thus allows for the possibilities of creating teaching strategies to address particular situations as they arise, as educators strive to offer rehabilitative and transformation possibilities for students.

\section{Transformative Learning Theory}

This section presents an overview of transformative learning theory and considers the ideas of the theorists who have contributed to its framework. The aim is to situate the theoretical approach as a context for understanding and addressing attachment theory through an educational perspective.

Paulo Freire (1970) outlined a model of transformative learning that is centred on the premise of conscientization or consciousness-raising. His approach was designed with a desire to foster, through dialogue and problem posing, a means of addressing social, political, economic and cultural influence that impact peo- 
ples' lives. Freire saw language as an oppressive medium, where meaning is imbued by those in positions of authority or control of the particular issue or circumstance to which the language refers. He advocated taking back ownership of the language of authority by redefining meaning through the circumstance in which the group positioned itself, thus leading to social transformation. Freire proposed that this should be done through Praxis, a process of dialectic dialogue and problem posing leading to planned action. In this way, participating parties can illuminate and address the language of the social forces that impact their personal lives by taking ownership of the specific issue or problem and addressing it in a planned and cohesive manner. The process of praxis empowers people with a means of naming and taking ownership of, and defining, "meaning" in the world around them.

Mezirow's (2007) transformative theory of adult learning is concerned with the ways in which adults make sense of their individual life experiences. This psycho-critical perspective argues that adults learn what they seek to learn through a process of transforming their 'frames of reference'. This occurs when people actively challenge their existing knowledge, perception and perspective, and seek to find new information and meaning to revise that knowledge, perception and perspective. These new experiences can bring liberation in thinking as they offer the learner a means of addressing the limitations and misrepresentations of existing frames. 'Frames of reference' are contingent on the construction of meaning in the correlation of our assumptions, perceptions and the creation of experiences. Adult have habits of expectations through which we derive our meaning schemes through three filter codes. These are socio-linguistic, psychological and epistemic. Learning takes place when we either build on our existing frames of reference, acquire new ones or transform the existing models. This happens through engaging in critical discourse, by examining our perspective, listening to the perspective of others and re-evaluating the information. The social nature of the socio-linguistic experiences is seen to shape the sense of reality and thus the sense of self. For the psychological, our basis for understanding is set from a very young age and establishes a subconscious framework for the "reality" of feeling and acting in adulthood. Equally, our particular learning style will have a profound effect on how knowledge is acquired, absorbed and personalised.

Boyd's (1991) psychoanalytical approach to transformative learning sees it as a holistic and intuitive development. By making the unconscious conscious, transformative learning is a process where adults make meaning by seeking to illuminate the experiences of the past and strive to understand how the latent memories associated with them influence our understanding of the present. This is significant when dealing with a personal dilemma, like the loss of a loved one. He sees the ego as one aspect of the process, but the unconscious forces that drive compulsions, obsessions and latent reactions are much more important to illuminate. The individual must develop an awareness of this unconscious process by engaging in a wilful dialogue with their many manifestations. By illuminating and making sense of the unconscious, adults begin to develop a greater awareness of the forces that influence our everyday experiences. Through this active engagement, transformation occurs, leading to a personality change.

Daloz's contribution to transformative learning $(1986,1999)$ acknowledges the different stages of life development. Adults have different needs and requirement based on their age and life experiences. It's about our ability to recognise, make sense of and understand these stages and develop the new methodologies to deal with them that defines the transformative process. He views learning as a lifelong process that should facilitate the personal development of the individual. Daloz highlights the importance of telling and listening to the personal story in the transformative process. Through the process of dialogue, stories offer support, present challenges and provide a platform for the development of foresight (Merriam, 2007, p. 137-39). Reflecting on lived experiences allows learners to transition to the next developmental stage in their lives. Daloz places greater emphasis on personal change than changing the social structure. It is about consciousness raising for personal awareness (Dirkx, 1998, p. 6).

Through Freire's social transformation and the more personal transformative approaches of Boyd, Daloz and Mezirow, transformative learning is a type of learning that goes further than the attainment of knowledge based on content, memorising formulas or retaining facts and data. It requires adults to develop the confidence to think for themselves, to question the knowledge and assumptions accumulated throughout one's life-course. It required that development of a reflective mind-set that seeks to question all forms of pre- 
viously acquired knowledge. Transformative learning requires the concurrent reorganization of both cognitive and emotional representation. Through this process the learner's sense of self is altered and thus the learner is capable of developing new configurations of understanding and blueprints for action (Illeris, 2002, p. 61).

\section{The Role of the Educator}

A teaching methodology that incorporates an awareness and understanding of attachment theory offers educators working in prisons a means of forming a more comprehensive and dynamic approach to understanding and actively working with the attachment patterns, masculinities and the different learning style that are encountered in this adult education environment. The teachers' care, sensitivity and awareness of the possible historical underpinnings of the students' emotional life history and previous experience of educational institutions are critical considerations. Negotiating the relationship between teacher and student in this 'strange situation' is fraught with difficulty (Wright, 2004, p. 206, Elliot, 2007), leaving it all the more crucial to develop considered transformative teaching methodologies for the classroom. The key is to link personal experience with the experience of learning.

The thesis outlined here argues that social background, poor attachment experiences, and hegemonic masculinities, institutional and socio-cultural, have negatively impacted the majority of the male prison population. If we accept that this is the case, then for a student who has experienced negative educational attachment, the authority figure of the teacher may potentially represent an unconscious threat to the masculine self. Because attachment experiences are unconsciously reignited in adulthood, it is incumbent on the educator to engage with students in a manner that seeks to avoid the recreation of this historical dynamic. The contribution of the student must be prized and valued. "The most important single factor influencing learning is what the learner already knows" (Ausuble, 1968). The learner's life experience, presence in the room, and his involvement in class is a prized asset contributing to a transformative learning environment. The following section discusses how this transformative learning environment might be created.

\section{Mind-mindedness, Attachment and Transformative Learning}

Mein, et al (2002, p. 1717) identified mind-mindedness as a practice that focuses on the thinking and feeling processes of children. To provide a secure attachment base from which confident adult learning can take place, mind-mindedness can be utilised by the educational practitioner to create an emotionally secure learning environment for the adult students that attend their classes. To achieve this, both teacher and student must transform their mode of thinking and feeling by developing a greater understanding of the emotional process that is at play in all learning. This is where recognising the association between transformative learning, attachment and masculinities is critical, as personal attachment patterns inform the ability to engage with the transformative learning processes and by implication, students' inherent male identities. Adults who adopt an attachment style of parenting are constantly centring their attention on attempting to understand the correlation between emotional expression and cognitive development (Sears, W and Sears, M, 2001). Equally, "the tutor who is capable of understanding both the feelings and thinking processes of the [adult] learner will have the developmental dividend of a secure environment for learning and development" (Fleming, p. 9). Creating and developing this secure environment is the foundation of and basis for creating the conditions for transformative learning to take place. Once emotional security is placed at the centre of the teaching agenda, for both practitioners and students, educators can begin to incorporate the tenets of attachment by paying attention to the emotional needs of students, creating a safe environment for its appropriate expression, and guiding them to trust in their own abilities to take ownership of their learning. In adopting this approach, the practitioner can guide students towards transforming many aspects of their learning, but most importantly, the belief, confidence and pride in their abilities to learn.

Unlike the psychoanalytical tradition of Freud, attachment deals with an individual's real experience as opposed to the perceived experiences of the latter (Kennedy, p. 214). New experiences have the capacity to realign the 'frames of reference' for functioning working models of attachment for the adult. Based on a number of existing studies dealing with the nature of attachment and its pattern over the lifespan, evidence is beginning to accumulate to suggest that the internal working models and the classification of attachment can be influenced and altered during an individual's lifespan (Fonagy et al., 1996; Main and Hesse, 1990; Sroufe et al., 2005). Developing a teaching framework that utilises the interconnectedness of masculinities, attach- 
ment and transformative learning have the potential to offer practitioners a means of employing sensitivity, awareness and working practices that establishes teaching methodologies within carefully considered professional boundaries. Through consciousness raising and dialogue, students can be guided towards renaming and establishing psychological ownership of the learning space. It then becomes their classroom and the teacher becomes the facilitator. Such a methodological framework has the potential to present students and teachers with a secure base from which to explore new forms of learning (Gore, Jonathan S. and Rogers, Mary Jill, 2010). Under these conditions, the responsibility of the educator is to establish professional teaching practices that ground the teacher in the role of primary attachment figure, thereby providing students with the secure base, and the necessary means of attaining new perspectives of the self. Working with this knowledge means that the practitioner must also be cognisant of their own attachment pattern and its influence on their educational experiences and gender identities. This too requires a shift in consciousness as ownership of the learning space is negotiated. This can present difficult situations for the teacher, for we unconsciously draw on lifelong constructed emotional responses when dealing with 'strange situations'. By being attentive to the processes of attachment, educators can develop a greater awareness of their own reactions when faced with emotionally challenging situations. This has the potential to contribute to better management of these encounters on both a personal and professional level. Emotionally aware educators are better placed to respond in an appropriate manner to the students' needs. (Brookfield, p. 24). Therefore, mind-mindedness is central to our function as educators and rehabilitators. Understanding these male students' concept of their identity as men is inextricably linked to this. Their masculinities are the manifestations of the quest for the self. These male adult learners have established an image of identity through their life course. How they view the world and their place within it is contingent on their level of engagement with that experience on an intellectual, social and emotional level. This is why encouraging students to view these issues from a different perspective is so crucial. They must be reassured that in a learning environment it is okay to express doubt, ask questions, admit that you don't know the answers, express vulnerability and ask for help. Adult learners have the opportunity to acknowledge and reflect on their past experiences and begin to carve a new dynamic for themselves. This type of engagement with education has the potential to help these students challenge the structure of this embedded social conditioning, whilst implicitly challenging the internal working models of the self; in fact, both are mutually inclusive (Byliss, 2003).

Adopting attachment awareness as a methodological basis for transformative learning offers the opportunity for learners to (re)develop autonomy and a masculine identity other than that of prisoner. Practitioners' awareness and attention on attachment, delivered through a transformative learning framework, presents adult students with the possibility of exploring and changing perceptions of self-esteem and personal confidence, thus changing their perception of the masculine self. Drawing on the work of neurobiological studies that link the retention of brain plasticity and an increase in brain function through positive relationship building in psychotherapy, Kennedy argues that "Siegel's descriptions justify the claim that school personnel can play key roles in students' brain development - specifically in the rehabilitation of insecure attachment models. Student-teacher relationships could stimulate the growth of the integrated fibres of the brain and thus provide the underlying mechanisms for transforming an insecure to a secure mental model of attachment" (Kennedy, 2008, p. 215). Taking this awareness into account, educators working in prison are ideally placed to provide the sense of respect and empathy that acknowledges the historical influence and personal mind-set of the students. This is key in providing the transformative learning platform for the practice of critical reflection.

\section{Mind-Mindedness and Critical Reflection}

Critical reflection is an indispensable feature of the learning process. (Dewey, 2012, Ash, S.L., \& Clayton, P. H. (2009) Educators in prison must strive to encourage students to engage in critical reflection and develop new pathways and/or patterns of learning in their lives. It is important to develop these aptitudes in order to help students cultivate self-confidence in their abilities and reflect on life experiences. Teaching methodologies and practices must endeavour to provide these new pathways for students. Creating the classroom environment where participants feel emotionally secure is a delicate and skilful balancing act. As previously discussed, the historical attachment experience of a student attending an education class in prison can have a major influence on their emotional intelligence (Hamarta, Deniz, \& Saltali, 2009). This includes their experience of attachment as a child in the home, in school, in their respective communities. Consequently, their abil- 
ity to engage with and reframe previous acquired knowledge will be influenced by these experiences. Viewed through a gendered lens, they are men seeking to define themselves as men. Hayslett-McCall and Bernard (2002) have examined the link between attachment, masculinities and male crime rates. Their study revealed that there is a correlation between disrupted attachments in boys that leads to negative outcomes for men. They attributed what they termed low self-control as a longitudinal outcome of negative attachment in childhood resulting from poor parenting techniques. Their conclusion highlights that poor attachment has consequences of masculine development. This is not to say that inappropriate behaviours associated with masculinities should be tolerated or accepted, or that poor attachment alone leads to negative masculine development. But an awareness of the emotional impact, as manifested in negative masculine behaviour, should be considered in the context of the profile of the male student in the education prison environment. Notwithstanding, the nature of the educators' work in prison is to engage with students in terms of rehabilitation, including rehabilitation of their thinking and feeling processes. In the transformative framework of Daloz, encouraging students to practice critical reflection by linking their personal life histories with their studies provides a platform to invite participants to challenge their existing frames of reference (Costello and Warner, 2003, Behan, 2007). To effectively engage with transformative learning methodology, the educator must be cognisant of possible factors that have influenced their students' life history. Guiding students through an educationally appropriate exploration of their past should form part of the practice for building students' confidence in their ability to take responsibility for their own learning (Brookfield, 2006).

Through encouraging students to practice critical reflection in this manner, educators can employ a twofold approach to the promotion of the students' learning strategies. Firstly, there is the academic subject itself and the importance of teaching and conveying the content to participants. Secondly, there is the issue of how students learn - their established patterns of learning and/or dominant learning styles (Gardner, 2006). Drawing learners' awareness to this latter issue is as of equal importance as the academic subject itself and I go so far as to suggest, more important. Focusing on the 'how' of learning presents a space to reflect critically on these issues (Novak \& Gowin, 1984). Furthermore, educators need to work on creating a platform where learners can safely experience the emotions that emerge in this space as they are guided to re-define meaning and make the unconscious conscious in their lives (Dirkx, 2008).

Nurturing students' ability to effectively engage in the learning process instils confidence to advance their own methodology of knowledge acquisition and allows them to explore the many facets that underpin the experience of learning-it encourages them to take ownership of the learning process (McKinney \& Cotronea, 2011). Taking "ownership" of knowledge acquisition is shown to result in higher grades and lower levels of anxiety. It also reduces the likelihood of dropping out of learning programmes (Gore and Rogers, 2010). However, a greater outcome is the emergence of personal satisfaction and confidence building derived through personal autonomy.

However, critically reflective learning must be approached in a cautious manner. This type of exploratory learning involves a degree of emotional disorientation as it requires students to question pre-held assumption about previous learning and thus their sense of self (Belzer, 2004). This is where teachers' awareness of attachment offers psychological insight that enables educators to negotiate the student teacher relationship in an emotionally aware manner. Because this reflective process is emotionally unsettling, it requires the educator's attentiveness to mind-mindedness. For example, students' "resistance" to learning may be a form of defence - a means of protecting emotional vulnerability in relation to that sense of self - fear of failure, fear of being judged, unconscious historical reaction to the teacher, inherently developed through their established attachment patterns. "Learning resistance is mainly related to the interaction dimension and includes learning which is unwanted or contrary to the learner's values, preferences, understandings, etc" (Illeris, 2015). Educators are in the unique position to provide secure attachment in this learning setting, we must be constantly mindful of the thinking and feeling processes at play. For a large number of these male students, disorientation experienced in a learning situation has the potential to affect their often fragile, emotionally internalised perceptions of their male identities. It needs to be treated and handled with great care and sensitivity. Viewed through this lens, the educator is an educational attachment figure, nurturing an environment that encourages students to take ownership of their learning. In order to do this, educators must be securely fixed within the boundaries of a praxis framework (Freire, 1996). 
Moreover, a working knowledge of attachment theory affords practitioners a means of gaining insight into possible emotional blocks to learning. "The emotional (or psychodynamic) dimension is the dimension [of learning] encompassing mental energy, feelings and motivations. Its ultimate function is to secure the mental balance of the learner and thereby it simultaneously develops a personal sensitivity" (Illeris, 2003, p. 50). Therefore, encouraging students to take action to overcome these negative patterns can begin through positive focus on learning strategies in the classroom, with a teacher consciously aware of the significance of learners' attachment patterns. As a method for addressing this, students could be encouraged to draw attention to the educational attachment patterns in their lives and guided in exploring how this has impacted and shaped who they are as humans, their thought processes, morals and values. By using a learning journal, literate students can be encouraged to write about their experience of learning. In this way, students can begin to take personal responsibility for the reflective process (Stevens, D. \& Cooper, J., 2009).

As discussed earlier, emotional insight is a central element of effective learning and this must form a core component of the practitioners' methodology. This is why knowledge and working practice of attachment sharpens the practitioner's understanding of the emotional learning in any given classroom situation. This insight can help the practitioner promote students' self-confidence through exploring past experiences to develop greater awareness of their personal abilities and instil confidence in learning 'how to learn'. Encouraging the use of a learning journal is a tool that can help male prison students examine their learning and re-define new patterns in their lives. It has the potential to provide the platform for the development of new recourses for their masculine expression. This can help these men break the negative cycle of attachment in term of their masculinity and their ability to transform their lives (Karp, p. 68). By keeping a learning journal, students can engage in this reflective process by taking personal responsibility for their emotional development and learning. Encouraging 'personal responsibility' is crucial to increasing students' capacity to transform their 'frames of reference'. Trust is critical and creating the right environment is essential (Eaggleston and Gehring, 2000). This is particularly applicable to education in the prison setting because we must remember the person behind the number (Hall and Killacky, 2008). Within the constraints and the environmental circumstances that prison masculinities are defined, and the historical baggage that these students carry, it is all the more crucial for the educator to instil a sense of confidence in the learner to develop their potential and to view their world through different perspectives. The learner must become confident in their abilities to not alone complete learning tasks, but to actually engage with the process and overcome their previous negative experiences around learning. This building of trust and security can help students work on and map out new directions in their lives.

\section{Conclusion}

This paper has discussed the utilisation of attachment theory as a central tenet of an emotionally informed transformative teaching methodology in a correctional education setting. This has been discussed in relation to transformative learning and the masculinities that relate to this environment. The paper illuminated aspects to the psychological nature of adult education practices pertaining to this context. Attachment theory was discussed as a method for broadening our understanding of the ways in which internal frameworks, constructed to provide emotional security in childhood, remain an unconscious basis for the processing of adult emotional responses. In effect, childhood experiences influence the unconscious adult sense of the masculine self. The social and cultural context of masculinities were discussed to obtain an overview of hegemony as a shaping force for internalising the social dynamic of masculine practices. Masculinities are also seen to be reflected in the structures of state institutions and serve to reinforce the oppressive nature of social expectations and emotional illiteracy that permeates the essence of the learning experience - where learning is understood as a process of spiritual and emotional development, not just the reasoned and rational acquisition of knowledge. Prison masculinities serve to reinforce this cultural dynamic of dominance and subordination, leading to an even more restricted space for the positive exploration of the emotional self. The physical and emotional restrictions that are implicit with incarceration tend to reinforce the enactment of masculine practices.

In utilising attachment theory as a methodological foundation for praxis, the teachers' role is one of primary educational caregiver, utilising 'mind-mindedness' as a means of facilitating the exploration and emergence of these ideas within a secure learning environment. Transformative learning was considered in the context of rehabilitation, as a focus for critical reflection of the emotional masculine self, while being 
cognisant of the resistance that this critique entails. Ultimately, the educator is charged with facilitating a secure learning environment where the emotional developmental life histories of the students are given primary importance in the methodological approach of the practitioner. The life histories are the greatest asset and source of knowledge in the classroom and must be utilised in order for effective transformative learning to take place. By embracing a methodology that places the emotional dimension of learning at its core, education in prison can ground itself in the fundamental human learning condition that shapes all our lived experiences and provide the fulcrum for effectively addressing the learning needs of the students that attend prison schools. Educators in prison must endeavour to provide students with a sense of empowerment and self-belief. Developing teaching methodologies that reflect and offer insight into how these men have emotionally constructed and contextualised their status in the world is essential. This requires the educator to be aware of the nature of attachment theory and its emphasis on emotional security, and particularly, how it engages the unconscious presence of the emotional needs of the young child that exist in adulthood within all of us.

\section{References}

Aboim, S. (2010). Plural masculinities: The remaking of the self in private life. Surrey: Ashgate.

Ainsworth, M. D., Blehar, M. C., Waters, E., \& Wall, S. (1978). Patterns of attachment: A psychological study of the strange situation. Hillsdale, NJ: Eralbaum.

Ash, S.L., \& Clayton, P. H. (2009). Generating, deepening, and documenting learning: The power of critical reflection in applied learning. Journal of Applied Learning in Higher Education, 1(1), 25-48

Ausuble, D (1968). Educational psychology; A cognitive view. New York: Holt, Rinehart and Winston.

Bacik, I. (1998) Crime and poverty in Dublin: An analysis of the association between community deprivation, District Court appearance and sentence severity. In I. Bacik \& M. O'Connell (Eds.) Crime and Poverty in Ireland. Dublin: Roundhall, Sweet and Maxwell.

Belzer, A. (2004). "It's not like normal school": The role of prior learning contexts in adult learning. Adult Education Quarterly, 55 (1), 41-59. 19p doi:https://doi.org/10.1177/0741713604268893

Byliss, P. (2003). Learning behind bars: Time to liberate prison education. Studies in the Education of Adults, 35 (2), 157-172. doi:https://doi.org/10.1080/02660830.2003.11661480

Behan, C. (2010). Report from the European Prison Education Association. The Journal of Correctional Education 61(1), 2-4.

Biddle, B. J. (2001). Social class, poverty and education: Policy and practice. London: Routledge.

Blom, I., Hagemann, K. \& Hall, C. (Eds). (2000). Gendered nations: Nationalism and the gender order in the long nineteenth century. Oxford: Berg.

Brenner, I. (2009). Injured men: Trauma, healing and the masculine self. Janson Arson Publishers: USA

Brod, H. \& Kaufman, M. (Eds). (1994). Theorizing masculinities. Sage: London.

Brookfield, S. (1995). Becoming a Critically Reflective Teacher. Jossey-Bass: San Francisco Brookfield, S. (2006). The skillful teacher: On techniques, trust and responsiveness in the classroom. Jossey-Boss. San Francisco.

Bowlby, J. (1969). Attachment and loss, vol 1: Attachment. New York: Basic Books

Bowlby, J. (1973). Attachment and loss, vol 2: Separation, anxiety and anger. New York: Basic Books.

Bowlby, J. (1979). The making and breaking of affectional bonds. London: Tavistock.

Bowlby, J. (1988). A secure base: Clinical application of attachment theory. London: Routledge.

Bretherton, I. (1992). The Origins of attachment theory: John Bowlby and Mary Ainsworth. Developmental Psychology, 28, 759-775. doi:https://doi.org/10.1037/0012-1649.28.5.759

Brumbaugh, C. C. \& Fraley, C. R. (2003).Transference and attachment: How do attachment patterns get carried forward from one relationship to the next? Personality and Social Psychology Bulletin, 23(4), 552560 .

Cohen, J. W. \& Harvey, P. J. (2006). Misconceptions of gender: Sex, masculinity and the measurement of crime. The Journal of Men's Studies, 14, (2), 223-233. doi:https://doi.org/10.3149/jms.1402.223 
Connell, R. W. (2000). The men and the Boys. Polity: Cambridge.

Connell, R. W. (2001). Masculinities. Polity: Cambridge.

Connell, R. W. (2002). Gender. Polity: Cambridge.

Connell, R. W. (2003). Men, Gender and the State. In S. Ervø, \& T. Johansson, (Eds.), Moulding masculinities: Among men (pp. 15-28). Ashgate: Aldershot.

Costelloe, A, \& Warner, K. (2003). Beyond 'Offending Behaviour': The wider perspective of adult education and European prison rules. Paper presented at the 9th EPEA International Conference on Prison Education, Langesund, Norway.

Dewey, J. (2012). Democracy and education: An introduction to the philosophy of education. LaVergne, TN: Simon \& Brown.

Dirkx, J. M. (1998). Transformative learning theory in the practice of adult education: An overview. PAACE, Journal of Lifelong Learning, 7, 1-14.

Dirkx, J. M. (2008). The meaning and role of emotions in adult learning. New Directions for Adult \& Continuing Education, 120. 7-18. doi:https://doi.org/10.1002/ace.311

Dudink, S., Hagemann, K. \& Tosh, J. (Eds.), (2004). Masculinities in politics and war. Manchester: Manchester University Press.

Eaggleston, C. \& Gehring, T. (2000). Democracy in prison education. Journal of Correctional Education, 51, (3), 306-310.

Eden, C. (2017). Gender, education and work: Inequalities and intersectionality. Retrieved from https://ebookcentral.proquest.com

Elliot, L. (2007). Security without care: Challenges for restorative values in prison. Contemporary Justice Review, 10,(2), 193-208. doi:https://doi.org/10.1080/10282580701372079

Esperian, J. H. (2010). The effect of prison education programs on recidivism. Journal of Correctional Education, 61(4), 316-334.

Evan, T. \& Wallace, P. (2008). A prison within a prison? The masculinity narratives of male prisoners. Men and Masculinities, 10(4), 484-507. doi:https://doi.org/10.1177/1097184X06291903

Fabelo, T. (2002). The impact of prison education on community reintegration of inmates: The Texas case. Journal Of Correctional Education, 53(3), 106-110.

Farrington, D. P. (2002). Developmental criminology and risk-focused prevention. In M. Maguire, R. Morgan, \& R. Reiner (Eds.), The Oxford handbook of criminology (pp. 657-701). Oxford: Oxford University Press.

Fleming, Ted. (2007). Picking wild flowers and orchids: Attachment theory and the implication for adult education. Radical Learning for Liberation 2. Maynooth Adult and Community Education (MACE), Maynooth. 79-94.

Fonagy, P., Steele, M., Steele, H., Leigh, T., Kennedy, R. \& Mattoon, G. (1996). The relation of attachment status, psychiatric classification, and response to psychotherapy. Journal of Consulting and Clinical Psychologist, 64(1), 22-31. doi:https://doi.org/10.1037/0022-006X.64.1.22

Freire, P. (1996). Pedagogy of the oppressed. London: Penguin Books.

Gardner, H. (2009). Multiple intelligences; New horizons. Basic: New York.

Gerber, J. \& Eric J. Fritsch, E. J. (1995). Adult academic and vocational educational programs: A review of recent research. Journal of Offender Rehabilitation, 22 (1-2), 119-142.

Giddens, A. (2009). Sociology. Polity: Cambridge

Goleman, D (2004). Emotional intelligence. London: Bloomsbury

Gore, J. S. \& Rogers, M. J. (2010). Why do I study? The moderating effect of attachment style on academic motivation. The Journal of Social Psychology, 150,(5), 560-578. doi: https://doi.org/10.1080/00224540903365448

Hall, R. \& Killacky, J. (2008). Correctional Education from the perspective of the prison student. The Journal of Correctional Education, 59 (4), 301-320. 
Hamarta, E., Deniz, M., \& Saltali, N. (2009). Attachment styles as a predictor of emotional intelligence. Educational Sciences: Theory \& Practice, 9(1), 213-229.

Hazan, C and. Shaver, P. (1987) Romantic love conceptualized as an attachment process. Journal of Personality and Social Psychology, 52(3), 511-514. doi:https://doi.org/10.1037/0022-3514.52.3.511

Hayslett-McCall, K. \& Bernard, J. (2002). Attachment, masculinity and self-control: A theory of male crime rates. Theoretical Criminology, 6 (1), 5-33. doi:https://doi.org/10.1177/136248060200600101

Haywood, C. \& Mac an Ghaill, M. (2003). Men and masculinities: Theory, research and social practice. Buckingham. Open University Press.

Haywood, C. \& Mac an Ghaill, M. (2013). Education and masculinities: Social, cultual and global transformations. Oxon. Routledge.

Hearn, J. (2006). Men in the public eye. London: Routledge

Hewitson, G. (2001). Feminist economics: Interrogating the masculinity of rational economic man. Journal of Economic Issues, 35 (1), 219-221. doi:https://doi.org/10.1080/00213624.2001.11506355

Hughes, E. (2012). Education in prison: Studying through distance learning. Farnham: Routledge.

Hill, D. \& Cole, M. (Eds.) (2004). Schooling and equality: Fact, concept and policy. Routledge Falmer. Oxon

Illeris, K. (2002). The three dimensions of learning: Contemporary learning theory in the tension field between the cognitive, the emotional and the social. Leicester: Niace Publications.

Illeris, K. (2003). Transformative learning-From the perspective of a comprehensive (adult) learning theory. In C. Aalsburg Wiessner, S. R. Meyer, N. Lloyd Pfhal \& P. G. Neaman (Eds) Transformative Learning in Action: Building Bridges Across Contexts and Disciplines - Proceedings of the Fifth International Conference on Transformative Learning (pp. 247-252). New York: Teachers College, Columbia University.

Illeris, K (2015). The development of a comprehensive and coherent theory of learning. European Journal of Education, 50 (1), 29-40. doi:https://doi.org/10.1111/ejed.12103

Irish Penal Reform Trust. (2017). Latest Prison Figures. Retrieved Apri1 9, 2017, from http://www.iprt.ie/prison-facts-2

Jewkes, Y. (2002). Captive audience: Media, masculinity and power in prisons. Devon. Willan

Karp, D. R. (2010). Unlocking men, unmasking masculinities: Doing men's work in prison. The Journal of Men 's Studies, 18 (1), 63-83. doi:https://doi.org/10.3149/jms.1801.63

Kennedy, B. (2008). Educating students with insecure attachment histories: towards an interdisciplinary theoretical framework. Pastoral Care in Education, 26, (4), 211-230. doi:https://doi.org/10.1080/02643940802472148

Kimmel, M. (2005). The history of men: Essays on the history of American and British masculinities. New York. SUNY.

Kimmel, M. (2016). The gendered society. Oxford: Oxford University Press

King, D. (2002) Parents, children, and prison: Effects of Parental Imprisonment on children. Dublin: Centre for Social and Educational Research, Dublin Institute of Technology.

Lochner,L.,\& Moretti,E.(2004). The effect of education oncrime: Evidence from prisoninmates, arrests, and self-reports. The American Economic Review, 94(1), 155-189.doi: https://doi.org/10.1257/000282804322970751

Main, M., \& Hesse, E. (1990). Parents' unresolved traumatic experiences are related to infant disorganized attachment status: Is frightening and/or frightened parental behaviour the linking mechanism? In M. T. Greenberg, D. Cicchetti, \& E.M. Cummings (Eds.), Attachment in the preschool years, pp, 121-160. Chicago: University of Chicago Press

Magrath, B. (2006). Towards an understanding of Irish Prison Education. Retrieved 29 September, 2015 from www.coppingon.ie/PDF\%20.../Bonnies\%20paper.doc

Mastrorilli, M. E. (2016). With pell grants rising: A review of the contemporary empirical literature on prison postsecondary education. Journal of Correctional Education, 67(2), 44-60

Mayo, P. (2008). Antonio Gramsci and his relevance for the education of adults. Educational Philosophy and Theory, 40, (3), 418-435. doi:https://doi.org/10.1111/j.1469-5812.2007.00357.x 
McKinney, D. \& Cotronea, M. (2011). Using self-determination theory in correctional education program development. Journal of Correctional Education. 62 (3), 175-193.

Merriams, S. B., Caffarella, R. S., \& Baumgartner, L. M. (2007) Learning in adulthood: A comprehensive guide. San Francisco: Jossey-Bass.

Messerschmidt, J. W. (1993). Masculinities and crime: critique and reconceptualization of theory. Maryland: Rowan and Littlefield.

Mezirow, J. (1990) Fostering critical reflection in adulthood: A guide to transfromative and emancipatory learning. San Francisco. Jossey-Bass Publishers.

Mezirow, J. (2007). Adult education and empowerment for individual and community development. In B. Connolly, T. Fleming, D. McCormack \& A. Ryan (Eds.), Radical learning for liberation 2, Maynooth: MACE. $10-17$.

Morgan, M. and Kett, M. (2003). The prison adult literacy survey: Results and implications. Dublin: Irish Prison Service.

Novak, J. \& Gowin, D. (1984). Learning how to learn. Cambridge: Cambridge University Press. doi:https://doi. org/10.1017/CBO9781139173469

O’Mahony, P. (1997). Prisoners in Mountjoy: A criminological and sociological survey, Retrieved 22 September, 2017 from www.drugsandalcohol.ie/3464/1/616-mountjoy.pdf.

O’Mahony, P. (Ed). (2002). Criminal justice in Ireland. Dublin: Institute of Public Administration.

Pease, B. (2012). The politics of gendered emotions: Disrupting men's emotional investment in privilege. Australian Journal of Social Issues, 47 (1), 125-142. doi:https://doi.org/10.1002/j.1839-4655.2012.tb00238.x

Phillips, J. (2001). Cultural construction of manhood in prison. Psychology of Men and Masculinity, 2, 13-23. doi:https://doi.org/10.1037/1524-9220.2.1.13

Parrotta, K. L. \& Thompson, Gretchen, H. (2011). Sociology of the prison classroom: Marginalized identities and sociological imagination behind prison bars. Teaching Sociology 39(2), 165-178. doi: https://doi.org/10.1177/0092055X11400440

Reeser, T. W. (2010). Masculinities in theory: An introduction. Oxford: Wiley-Blackwell. doi: https://doi.org/10.1002/9781444317312

Roberts, G. D. (2003). Shantaram. Australia: Scribe

Sabo, D. Kupers, T. A. \& London, W. (Eds). (2001) Prison masculinities. Philadelphia: Temple University Press

Sabo, D. Kupers, T. A. \& London, W. (2001a) Gender and the politics of punishment. In D. Sabo, T. A. Kupers \& W. London (Eds), Prison Masculinities. Philadelphia: Temple University Press

Share, P., Tovey, H. and Corcoran, M. P. (2007). A Sociology of Ireland. Dublin: Gill and MacMillan.

Skelton, C., B. Francis, \& L. Smulyan, (Eds). (2006). The SAGE handbook of gender and education. Sage: London.

Sroufe, L. A., Egeland, B., Carlson, E., \& Collins, W.A. (2005). The development of the person: The Minnesota study of risk and adaptation from birth to adulthood. NewYork: Guilford Press.

Stevens, D. \& Cooper, J. (2009). Journal keeping: How to use reflective writing for effective learning, teaching, professional insight and positive change. Sterling, Va: Stylus Publications.

Tennant, M. (2006). Psychology and adult learning. London: Routledge.

Damien Carberry is on a career break from his position with City of Dublin Education and Training Board at Wheatfield Prison Education Unit, Dublin, where he has been employed as a Sociology teacher since September 2008. He is currently contracted as an Assistant Professor in the General Studies Department with the Higher Colleges of Technology in the United Arab Emirates. Some of his research interests include masculinities, the role of emotion in learning, the psychology of adult learning, the implications of childhood experiences for adult learning and transformative learning. He holds a $\mathrm{PhD}$ in social and cultural History, a Post-Graduate Diploma in Adult and Community Education and a BA in Sociology and History. 